\title{
Porównanie strategii translatorskich w polskich przekładach wybranych komiksów z serii Asteriks
}

\section{Abstrakt:}

Celem artykułu jest porównanie strategii translatorskich zastosowanych przez Jolantę Sztuczyńską i Jarosława Kiliana w przekładach na język polski tych samych dziesięciu tomów serii komiksowej Asteriks René Goscinnego i Alberta Uderzo. Najtrudniejszym zadaniem, przed którym stanęli tłumacze, było przełożenie zarówno elementów humorystycznych adresowanych do czytelnika dziecięcego, jak i tych przeznaczonych dla odbiorcy dorosłego. Przyjęcie przez Sztuczyńską i Kiliana odmiennych metod jest widoczne przede wszystkim w przekładach nazw własnych, dialektów, tekstów wpisanych w obraz, cytatów, tekstów piosenek oraz innych treści, które naszpikowane są aluzjami kulturowymi i językowymi.

Słowa kluczowe:

adaptacja, Albert Uderzo, Asteriks, Jarosław Kilian, Jolanta Sztuczyńska, komiks francuski, podwójny adresat, przekład, René Goscinny

\section{Comparison of Translation Strategies in Polish Versions of Selected Comics in the Asterix Series}

\section{Abstract:}

The aim of the article is to compare the translation strategies used by Jolanta Sztuczyńska and Jarosław Kilian in Polish translations of the same ten volumes of the comic series Asterix by René Goscinny and Albert Uderzo. The most difficult task faced by Sztuczyńska and Kilian was translating the humorous elements of the books, both these addressed to the child reader and those appealing to the adult. The differences between their methods of translation are visible, above all, in the translations of proper names, dialects, texts embedded in the picture, citations, lyrics, and other content that includes cultural and linguistic allusions.

Key words:

adaptation, Albert Uderzo, Asterix, Jarosław Kilian, Jolanta Sztuczyńska, French comics, double addressee, translation, René Goscinny

* Joanna Kierska - lic., przygotowuje pracę magisterską w ramach podwójnego dyplomu na Wydziale Polonistyki Uniwersytetu Warszawskiego i w Jednostce Szkoleniowo-Badawczej (UFR) Studiów Słowiańskich Uniwersytetu Sorbony (Francja), dotyczącą obrazu dzieciństwa w komiksach autobiograficznych. Kontakt: jm.kierska@student.uw.edu.pl. 


\section{Wprowadzenie}

A 1 steriks „narodził się” 29 października 1959 roku w pierwszym numerze oraz rysownikowi Albertowi Uderzo (1927- ), nie śniło się wówczas, że postać małego Gala już niedługo stanie się rozpoznawalna na całym świecie. Dwa lata po prasowym debiucie tego bohatera francuskie wydawnictwo Dargaud opublikowało w twardej oprawie komiks Astérix le Gaulois (Goscinny, Uderzo, 1961). Choć pierwszy tom serii sprzedał się początkowo zaledwie w sześciu tysiącach egzemplarzy, wkrótce stała się ona przebojem i podbiła rynki księgarskie większości europejskich krajów, a później - również innych kontynentów (Kessler, 1995, s. 9-23). Po śmierci Goscinnego Uderzo wziął na siebie również pisanie scenariuszy (tomy 25.-34. ${ }^{1}$ ), a następnie przekazał pałeczkę młodszym artystom, scenarzyście Jeanowi-Yves'owi Ferriemu oraz ilustratorowi Didierowi Conradowi. Wciąż jednak pilnował, aby Asteriks nie stracił nic ze swojego pierwotnego stylu. Dotychczas (stan na grudzień 2019 roku) opublikowano 38 tomów cyklu, które zostały przetłumaczone na ponad sto języków.

W Polsce tom otwierający serię ukazał się po raz pierwszy pod tytułem Przygody Gala Asteriksa (Goscinny, Uderzo, 1961/1990) w tłumaczeniu Andrzeja Frybesa w wydawnictwie Egmont, które opublikowało również wszystkie kolejne omawiane w niniejszym artykule edycje (i w którym do dziś ukazują się nowo powstające tomy). Komiksy od drugiego do dwunastego tłumaczyła Jolanta Sztuczyńska, a w naszym kraju pojawiły się one w latach 1991-1993. W latach 1998-1999 wyszło zaś wznowienie w przekładzie Jarosława Kiliana, opatrzone leksykonem oraz mające inną szatę graficzną okładki (na wzór wydań niemieckich). Trzecie i czwarte wydania, nadal w przekładzie Kiliana, publikowane są - już bez leksykonu i z pierwotną wersją okładki - od roku 2008. Warto zauważyć, że pierwszy polski przekład ukazał się ponad trzydzieści lat po francuskiej premierze, obecnie natomiast premiera francuska i zagraniczna odbywają się zazwyczaj w tym samym dniu.

Sztuczyńska i Kilian przyjęli odmienne strategie translatorskie w zakresie tłumaczeń niektórych elementów tych samych komiksów z serii Asteriks. Artykuł ma na celu przedstawienie wynikłych z tej przyczyny różnic na wybranych przykładach z tekstów. Analiza obejmuje tomy od drugiego do jedenastego:

Wyjątek stanowi tom 32., Galijskie początki (Goscinny, Uderzo, 2003/2013), na który składają się przedrukowane krótkie opowieści, wcześniej rozsiane po różnych publikacjach i czasopismach. Autorem scenariuszy do większości z nich był Goscinny. 
- Złoty sierp (Goscinny, Uderzo, 1962, 1962/1991b, 1962/1998f);

- Asteriks i Goci² (Goscinny, Uderzo, 1963, 1963/1992b, 1963/1999a);

- Asteriks gladiator (Goscinny, Uderzo, 1964, 1964/1992a, 1964/1998a);

- Wyprawa Asteriksa dookoła Galii (Goscinny, Uderzo, 1965b, 1965/1992f, 1965/1998e);

- Asteriks i Kleopatra (Goscinny, Uderzo, 1965a, 1965/1992c, 1965/1998b);

- Walka wodzów (Goscinny, Uderzo, 1966c/1992e, 1966/1998d);

- Asteriks u Brytów (Goscinny, Uderzo, 1966a/1992d, 1966/1998c);

- Asteriks i Normanowie (Goscinny, Uderzo, 1966b/1993a, 1966/1999b);

- Asteriks legionista (Goscinny, Uderzo, 1967/1993b, 1967/1999c);

- Tarcza Arwernów (Goscinny, Uderzo, 1968/1993c, 1968/1999d).

Różnice przekładu między wydaniem drugim a trzecim i czwartym są niewielkie, nie zostały więc wzięte pod uwagę. Komiksy o Asteriksie doczekały się w Polsce kilku opracowań (m.in. Cataldi, 2009; Chantry, 2002; Dąmbska-Prokop, 1997), niemniej tylko jedno z nich - w języku francuskim, Le Tour de Pologne d'Astérix ? Katarzyny Sadowskiej-Dobrowolskiej (2015) - zawiera porównanie dwóch tłumaczeń (na przykładzie tomu Wyprawa dookoła Galii).

\section{Teoria przekładu komiksu dla dzieci}

Asteriks należy do dwóch porządków genologicznych - jest komiksem oraz utworem literatury dziecięcej. Tłumaczenia tej serii można studiować za pomocą narzędzi wypracowanych przez badaczy przekładu literatury dziecięcej, ponieważ do opisu komiksu w ogóle można zastosować metodologię teoretycznoliteracką, o czym pisze Michał Wróblewski (2011):

Choć traktuję komiks [...] jako sztukę osobną, która wykształciła własny język oparty na jedności ikonolingwistycznej, uważam za istotne badanie tego zjawiska w kontekście literatury, przy jednoczesnym użyciu narzędzi teoretycznoliterackich. Powodem moich przekonań jest przede wszystkim literackość narracji w komiksie oraz jego rodowód. [...] każdy komiks ma na celu opowiedzenie historii, a swoją fabularność zawdzięcza wzorcom literackim (s. 53).

2 Polski wydawca zmienił oryginalną kolejność tomów. Tom Asteriks i Goci (Goscinny, Uderzo, 1963) ukazał się we Francji jako część trzecia, natomiast w pierwszym polskim wydaniu - jako część siódma, a w drugim - jako ósma.

3 W kolejnych wydaniach komiks ukazał się jako Wyprawa dookoła Galii. Dla uproszczenia w dalszej części artykułu tom funkcjonuje właśnie pod tym tytułem. 
Teza Wróblewskiego sprawdza się tym bardziej w przypadku badań translatologicznych nad komiksem, które naturalnie skupiają się na warstwie językowej, a nie ikonograficznej.

$\mathrm{W}$ odniesieniu do literatury dziecięcej jednym z najistotniejszych zagadnień translatorskich jest wzajemny stosunek terminów „adaptacja” i „przekład”“. Są to pojęcia przez niektórych autorów traktowane jako przeciwstawne, przez innych zaś - jako prawie równoważne. Monika Adamczyk-Garbowska (1988) pisze:

O ile spotykamy bardzo wiele definicji przekładu, o tyle trudno spotkać definicję adaptacji. Wynika to z faktu, że w przypadku przekładu, który implikuje takie cechy jak wierność, adekwatność, ekwiwalentność itp., jakkolwiek by były one zrozumiane, wymagana jest absolutna precyzja w oddaniu wszystkich aspektów oryginału. Są to więc definicje stosunkowo ograniczone. Natomiast w przypadku adaptacji margines swobody jest bardzo szeroki (s. 142).

Pojęcie adaptacji może obejmować wiele zabiegów: zarówno zmianę medium, skrócenie czy infantylizację tekstu, jak i dostosowanie przekładanych treści do potrzeb młodego odbiorcy. Dla badaczy literatury dziecięcej najistotniejszy jest ostatni spośród tych zabiegów. Göte Klingberg (1976) stosuje pojęcie "podwójnej adaptacji”" - dowodzi, że pierwszej adaptacji dokonuje autor tekstu, świadomie lub nie, poprzez dostosowanie treści do poziomu intelektualnego dziecka. Stopień tego uproszczenia treści Klingberg nazywa „stopniem adaptacji”, a głównym zadaniem tłumacza, jak dowodzi, jest utrzymanie tego samego stopnia adaptacji w przekładzie: „Tłumaczenie nie powinno być trudniejsze ani łatwiejsze w odbiorze, bardziej lub mniej ciekawe” (s. 86). Drugi stopień adaptacji to tzw. „kulturowa adaptacja kontekstowa” (s. 86), czyli oddanie realiów świata przedstawionego w sposób zrozumiały dla dziecięcego odbiorcy. Takie działanie, według tego autora, należy podjąć jedynie w sytuacji, gdy tekst przełożony „słowo w słowo” byłby niezrozumiały, np. w przypadku nazw własnych ludzi i miejsc, nazw jedzenia, aluzji literackich. Badacz podkreśla jednak, że ważną funkcją literatury dla dzieci jest przekazywanie wiedzy o innych kulturach, nie powinno się więc ograniczać zbytnio pierwotnego kontekstu. Ostatecznie adaptację uważa za proces niepożądany, lecz dopuszczalny, jeżeli ma znacząco ułatwić rozumienie tekstu młodemu czytelnikowi w kraju docelowym:

4 Tłumaczenie i przekład są tu traktowane jako pojęcia synonimiczne, choć autorka artykułu jest świadoma prób nadania im odrębnych znaczeń (Barańczak, 1990/2004, s. 15).

5 Jeśli nie podano inaczej, wszystkie tłumaczenia autorki artykułu - Joanny Kierskiej. 
Zakładając, że zmiany stylistyczne, np. oddawanie frazeologizmu w języku źródłowym przez użycie frazeologizmu o podobnym znaczeniu w języku docelowym, są dopuszczalne przy tłumaczeniu, istnieją zdecydowane powody, dla których przekładu powinno się dokonywać słowo w słowo (Klingberg, 1986, s. 109).

Riitta Oittinen (1993) w książce I am Me - I am the Other: On the Dialogics of Translating for Children zdecydowanie polemizuje zarówno z tą tezą, jak i z innymi koncepcjami Klingberga. Według tej autorki adaptacja jest procesem niezbędnym, niesłusznie traktowanym przez innych badaczy jako uwłaczający zawartości oryginału. Utarła się, jak pisze, „[...] tradycyjna dychotomia: przekład - dobry, adaptacja - zła, przekład - niewidoczny, adaptacja - widoczna” (s. 96). Badaczka uważa, że różnica między jednym a drugim działaniem zależy przede wszystkim od punktu widzenia czytelnika. Ponieważ „[...] adaptacja jest częścią przekładu, a nie procesem równoległym [...], przekład spełnia swój cel, jeśli »ja« czytelnika przekładu spotyka się z »ty« tłumacza, autora czy ilustratora" (s. 96). Tłumaczenie powinno więc przede wszystkim realizować funkcje tekstu zamierzone przez autora, jakiekolwiek by one nie były, i jeżeli do osiągnięcia tego celu niezbędne jest oddalenie się od dosłownego przekładu, należy się na nie zdecydować.

Klingberg (1986, s. 10) uważa adaptację za przejaw braku szacunku wobec czytelnika i autora. Według Oittinen (2000, s. 97) przeciwnie, najlepszym sposobem na okazanie czytelnikowi szacunku jest uzyskanie pełnego i wartościowego przekładu (czy też adaptacji) przez przyznanie tłumaczowi prawa do interpretowania tekstu. Adaptacja i tłumaczenie to w jej opinii coś więcej niż przekładanie słów, ponieważ tłumacz przelewa na tekst swoje emocje i przywiązanie do danego utworu. Autorka podkreśla, że tłumacz jest w pierwszej kolejności czytelnikiem, który podróżuje między tekstami, a jego interpretacja oryginału jest czynnikiem decydującym o tym, co dotrze do odbiorcy z innego kraju i posługującego się innym językiem (s. 16). W przypadku komiksów, a w szczególności tych wchodzących w skład serii Asteriks, gdzie tak wiele elementów humorystycznych opiera się na słownych kalamburach połączonych z przekazem wizualnym, nie sposób mówić o przekładzie „\$łowo w słowo”. Przyznaje to sam Albert Uderzo w wywiadzie: „Pilnujemy jakości przekładów, dając każdy z nich do ponownego przetłumaczenia na francuski. Zawsze jednak bronię tłumaczy, bo w zasadzie nie tłumaczą oni Asteriksa, tylko tworzą jego adaptację" (Obremski, 2015, s. 103). W niniejszym artykule stosowane w analizie komiksów pojęcia adaptacji i przekładu są używane w znaczeniu przyjętym przez Oittinen - bez nacechowania aksjologicznego, jako terminy bliskoznaczne. Adaptacja jest więc 
częścią przekładu, charakteryzującą się swobodniejszym dostosowywaniem tekstu do docelowego czytelnika.

Tłumacz musi zatem postawić sobie pytanie o to, kto jest docelowym czytelnikiem Asteriksa. Czy na pewno wszystkie treści adresowane są do dziecka? W 1959 roku Uderzo i Goscinny byli współwłaścicielami małego wydawnictwa Édifrance/Édipresse. Pewien ich znajomy „[...] nie mógł znieść, że jego dzieci czytają wyłącznie komiksy amerykańskie. Chciał, by poznały kulturę francuską. Zaproponował więc Hebrardowi [właśc. Hébrardowi, trzeciemu z założycieli oficyny], żeby [...] wydawnictwo zajęło się stworzeniem takiej gazety" (Busnel, b.d.). Kilka miesięcy później Uderzo, Goscinny i Hébrard zaczęli wydawać jeden z pierwszych francuskich tygodników komiksowych dla dzieci i młodzieży, Pilote, i publikować w nim m.in. plansze Asteriksa. W zamyśle komiks ten był więc adresowany do młodych czytelników. Autorzy mieli jednak bardziej ambitne plany i postanowili poszerzyć grono odbiorców. Uderzo wspomina:

Chcieliśmy stworzyć komiks, który byłby jednocześnie adresowany i do dzieci, i do dorosłych. By to osiągnąć, trzeba było dopracowywać scenariusz i wyostrzyć humor. Przypominam sobie, że wtedy poczucie humoru Goscinnego było postrzegane jako zbyt intelektualne... a ja pokładałem się ze śmiechu, słysząc jego dowcipy! Z kolei moje rysunki uważano za zbyt groteskowe, gdyż lubiłem rysować duże nosy [...]. Tworząc Asteriksa, René mógł dać upust swemu rzekomo przeintelektualizowanemu humorowi, a ja moim rzekomo groteskowym rysunkom. Oto, dlaczego Asteriks i jego kumple mają wielkie nosy, a humor jest zwykle oparty na intelektualnych gagach (Busnel, b.d.).

Taka fuzja poczucia humoru scenarzysty i spontanicznego stylu rysownika okazała się receptą na podbicie serc czytelników w każdym wieku. Można więc mówić o wieloadresowości lub podwójnym adresacie serii Asteriks.

Zohar Shavit (1986) w monografii Poetics of Children's Literature stawia (i udowadnia) tezę, że utwory przeznaczone dla młodego czytelnika funkcjonują w dwóch systemach - literatury dziecięcej i tej dla dorosłych. Książka dla dzieci ma szansę zaistnieć na rynku wyłącznie wtedy, gdy zyska aprobatę osób dojrzałych, które są decydentami w procesie jej tworzenia, dystrybucji i zakupu. Do kanonu literatury dziecięcej wchodzą więc teksty ambiwalentne - skrywające autentyczny, silny zwrot do dorosłego: „Tekst jest zbudowany z co najmniej dwóch koegzystujących modeli [nadawczo-odbiorczych] - jednego bardziej konstytutywnego, drugiego mniej" (s. 68). Pierwszy model, ogniskujący się na dziecięcym czytelniku, skupia się na dosłownych sensach tekstu. Drugi natomiast, skoncentrowany na dorosłym, jest realizowany na różne sposoby: 
przez parodię pewnych elementów, zmianę ich funkcji, dodanie ukrytych treści czy zaburzenie ich hierarchii. Autorka zaznacza jednak, że jest to klasyfikacja uproszczona, oparta na dychotomicznym podziale czytelników na dzieci i dorosłych. Należałoby raczej wziąć pod uwagę doświadczenia odbiorcy i sposób realizowania przez niego procesu czytania, co nie wyklucza się z podziałem wiekowym, ale też niekoniecznie się z nim pokrywa (s. 70). Według autorki Poetics of Children's Literature teksty nie są tłumaczone jedynie z języka na język, ale też z systemu na system (s. 111), tak więc najważniejszy jest nie wiek odbiorcy, lecz system kulturowo-językowy, który tenże odbiorca rozumie (s. 70). Shavit odnosi się również do pojęcia adaptacji, jednakże nazywa tak jedynie procesy sprowadzające się do „upraszczania” tekstów dla dorosłych w dziecięcych wersjach tych utworów (s. 68).

Wszyscy przywołani badacze ${ }^{6}$ są zgodni co do faktu, że odbiorca w kraju docelowym ma inne zaplecze kulturowe niż czytelnik w kraju, w którym powstał oryginał, i że nie jest to zależne od wieku. W prezentowanej w niniejszym artykule analizie zostanie jednak użyty uproszczony podział na czytelnika dorosłego i dziecięcego, który można w domyśle odczytywać jako oparty na różnicy między bardziej i mniej świadomymi kulturowo odbiorcami. W przypadku Asteriksa, tekstu tak głęboko osadzonego w kulturze francuskiej, odbiór za granicą, w przekładzie, zawsze jest spłycony. Po pierwsze, jak w każdym tłumaczeniu, pewne elementy „zaginą”, a po drugie, te, które uda się przełożyć, jest w stanie wychwycić tylko Francuz lub osoba bardzo blisko z Francją związana. Zgodnie z koncepcją Shavit, komiksy z serii Asteriks są ponadto odczytywane w inny sposób przez czytelnika dorosłego, a w inny - przez dziecko. Powstająca dzięki wieloadresowości familijność serii jest jedną z przyczyn jej sukcesu - można te komiksy czytać wielokrotnie, w różnym wieku, i za każdym razem odkrywać w nich coś nowego. Jest to jednak dodatkowe utrudnienie dla tłumacza, który musi dotrzeć do obu grup docelowych oraz sprawić, aby ich członkowie jak najpełniej skorzystali z zawartego w komiksach humoru. W artykule o tłumaczeniu portugalskich komiksów, na marginesie poświęconych im rozważań, Tomasz Pindel (2005) pisze:

Większość kłopotów, z jakimi może się spotkać tłumacz komiksów, wiązać się będzie z przekładem humoru językowego. Kanonicznym przykładem jest seria przygód Asteriksa autorstwa Gościnnego i Uderzo, bijąca rekordy popularności na całym świecie. Dialogi Galów skrzą się dowcipem, Gościnny,

${ }^{6}$ Więcej koncepcji dotyczących adresata literatury dziecięcej opisuje m.in. Hanna Dymel-Trzebiatowska (2017). 
scenarzysta, przepada za grami słów, kalamburami, nie stroni też od aluzji do współczesności. Jednak w zasadzie trudności te mają ściśle „literacki” charakter, nie różnią się od analogicznych problemów w przypadku tekstów literackich (s. 114).

W niniejszym artykule we fragmentach dotyczących humoru w tekstach dwojga tłumaczy Asteriksa zostanie wykorzystana terminologia Ewy Teodorowicz-Hellman (1997). Autorka łączy definicje komizmu Michała Głowińskiego (1988) i Marie Collins Swabey (1961), analizując je w odniesieniu do literatury dziecięcej. Dzieli więc komizm na: komizm sytuacyjny, komizm słowny, humor, satyrę i ironię. Komizm sytuacyjny, gdzie „śmiech wzbudzany jest przez różne sytuacje[,] np. nieuzasadnioną powtarzalność i mechaniczność, zaskoczenie oczekiwań czytelnika [...], jest właściwie formą aintelektualną i w zasadzie bezrefleksyjną" (s. 199), którą rozumieją nawet dzieci w wieku przedszkolnym. Bardziej zaawansowaną formą jest komizm słowny, wymagający większej wiedzy o języku i świecie, występujący często w paronomazjach i kalamburach. Humor stanowi psychiczną predyspozycję do odbioru różnych przejawów komizmu, zależną od wieku, natomiast satyra i ironia, mające na celu parodiowanie i ośmieszanie przywar ludzkich, zostają odczytane na płaszczyźnie percepcji dorosłego i zazwyczaj nie są stosowane z myślą o dziecięcym odbiorcy. W Asteriksie występują wszystkie $\mathrm{z}$ wymienionych typów komizmu. Dla dziecka najzabawniejsza będzie zapewne groteskowość nieskomplikowanych psychologicznie postaci, spontaniczny styl rysunków, sceny bitew czy powtarzalność fabuły, czyli komizm sytuacyjny. Dorosłego rozbawią za to nawiązania intertekstualne, historyczne czy polityczne, od których aż skrzy się w Asteriksie, a dziecko prawdopodobnie większości z nich nie zauważy. Pomiędzy komizmem sytuacyjnym a słownym plasować możemy gry słów, stereotypy i satyrę - zależnie od wieku, inteligencji i doświadczenia odbiorcy, okażą się one mniej lub bardziej zrozumiałe. Satyra widoczna jest szczególnie w przypadku odniesień do współczesności lub ogólnych ludzkich przywar. Niejednokrotnie w Asteriksie pojawia się krytyka wielkomiejskiego życia, oportunizmu czy dążenia do władzy. Często w jednym kadrze obecne są dwa typy komizmu, np. na zasadzie obecności komizmu słownego na płaszczyźnie graficznej, a sytuacyjnego na płaszczyźnie językowej, co może stanowić nie lada wyzwanie dla tłumacza.

W komiksie przekładowi podlega nie tylko sama treść dialogów między bohaterami, lecz także tekst narracyjny, onomatopeje, napisy wpisane w obraz i parateksty, a tych elementów w Asteriksie nie brakuje. Dochodzi tu więc dodatkowe zadanie dla tłumacza komiksów, z którym zazwyczaj nie musi się 
borykać tłumacz gatunków stricte literackich - tekst i obraz muszą współgrać. Treść przekładu nie może być dużo krótsza ani dużo dłuższa niż oryginał, żeby dobrze wpasowywała się w przeznaczoną dla niej przestrzeń. Wówczas tekst pozostaje czytelny i nie tworzy wrażenia źle zagospodarowanego miejsca. W komiksie ogromne znaczenie ma też to, jak sam tekst wygląda. Należy więc zadbać o przełożenie graficznych wyróżników słownych, np. w przypadku redundancji komunikatu. Oznacza to, że gdy np. emocje bohatera zostają przekazane we wzmocniony sposób dzięki połączeniu obrazu i tekstu, tłumacz musi pamiętać o odpowiedniej pod względem graficznym formie wypowiedzi. Ma ona zazwyczaj ogromny wpływ na odbiór zakodowanych informacji, ponieważ w komiksie zapisane słowo niesie za sobą nie tylko treść, lecz także jego akustyczną reprezentację ${ }^{7}$. Autorzy Asteriksa stosują środki doskonale ilustrujące zarówno redundancję komunikatu, jak i wagę akustycznego odbioru treści. Widać to przede wszystkim w sytuacjach, gdy Galowie stykają się z innymi narodowościami - Uderzo i Goscinny na różne sposoby oddawali języki obce, bawiąc się często efektami „audiowizualnymi”. Goci „mówią” pismem gotyckim, co przywołuje brzmienie języka niemieckiego, Egipcjanie zaś - pismem obrazkowym wzorowanym na hieroglifach. Gdy postać mówi szeptem, litery są mniejsze, gdy krzyczy - większe, a piktogramy implikujące w tym przypadku złość (np. trupie czaszki czy wybuchające bomby) komunikują, że bohater wyraża się niecenzuralnie.

\section{Analiza porównawcza przekładów Asteriksa}

W poddanych analizie dziesięciu tomach Asteriksa, wydanych w przekładach Sztuczyńskiej i Kiliana, wyraźnie widać dwie odmienne ścieżki, które obrali tłumacze. Najbardziej wyraźne jest to w przypadku elementów komicznych, które w tej serii pojawiają się na każdym kroku i występują w najróżniejszej formie.

\section{Imiona bohaterów}

Pierwszy tom Asteriksa ukazał się w Polsce w przekładzie Andrzeja Frybesa i to ten tłumacz narzucił wiele rozwiązań, których Sztuczyńska i Kilian musieli się trzymać, aby zachować spójność serii. Każdy obóz rzymski, na wzór

7 Przekład audiowizualny i przekład komiksu operują często podobnymi narzędziami (Krajewska, Lipińska, 2013, s. 207-215). 
Akwarium, Rabarbarum, Relanium i Delirium (propozycja Frybesa), nosi nazwę z sufiksem -um i kojarzącą się z jakimś polskim słowem, a imiona galijskie kończą się na -iks, a nie -ix jak w oryginale. W większości omawianych tomów Asteriks i Obeliks wyruszają w podróż - po terytorium dzisiejszej Francji lub poza jej granice. Autorzy budują sobie w ten sposób przestrzeń do operowania stereotypami narodowymi czy regionalnymi, dialektami, językami obcymi, jak również aluzjami do współczesności.

Urszula Dąmbska-Prokop (1997) pisze, że twórcy Asteriksa:

[...] praktykują szereg odmian komizmu: sytuacyjny, językowy, komizm charakterów, i osiągają efekty ludyczne przy pomocy rozmaitych środków, w których ciężar spoczywa na wykorzystaniu zarówno stereotypów pojęciowych, jak i faktów językowych i rysunkowych, żerujących na tych stereotypach niekiedy aż do przesady (s. 79).

Uderzo i Goscinny stworzyli niezwykle bogaty świat rządzący się swoimi prawami. Jednym $z$ nich jest przypisanie imionom lub nazwiskom reprezentantów każdej narodowości ich wyłącznego sufiksu, czego tłumacze skrzętnie przestrzegają. Tak więc np. w Asteriksie legioniście zarówno u Kiliana (Goscinny, Uderzo, 1967/1999c, s. 26) jak i u Sztuczyńskiej (Goscinny, Uderzo 1967/1993b, s. 18), każdy Grek ma imię zakończone na -os (Olimpiados / Kolosandoros), Bryt na -aks (np. Effaks / Progrestaks), a Got na - yk (Figuralegoryk w obu wersjach). Jedyne znaczące odstępstwo od tej reguły występuje $\mathrm{w}$ tomie Asteriks i Normanowie. W oryginale przedstawiciele tytułowej nacji noszą nazwiska zakończone na -af. Sztuczyńska podąża za tym modelem, Kilian natomiast zmienia je na zakończone na -son. W efekcie wódz nordyckiego plemienia u Sztuczyńskiej nazywa się Olaf Grombaf (Goscinny, Uderzo, 1966/1993a, s. 9), a u Kiliana Olaf Zastafson (Goscinny, Uderzo, 1966/1999b, s. 17). Widać wyraźnie, że Sztuczyńska stara się jak najwierniej oddać oryginał, gdzie ta postać nosi nazwisko Grossebaf (Goscinny, Uderzo, 1966b, s. 9), czyli fonetycznie zapisany zlepek słów (grosse baffe - 'wielkie uderzenie', 'spoliczkowanie'). Aby nie zagubić charakterystycznych cech postaci, stosuje jako podstawę słowo grom, również kojarzące się z walecznością i odwagą Normanów. Zmianę wprowadzoną przez Kiliana można natomiast uzasadnić względami historycznymi (nawiązanie do skandynawskich patronimików), a wdzięczny sufiks -son daje wiele możliwości językowych popisów. W tabeli 1 wypisane zostały nazwiska Normanów wymieniane w jednym z kadrów komiksu przez wodza plemienia. 
TABELA 1. Nazwiska Normanów w oryginale (Goscinny, Uderzo, 1966b, s. 14) i w przekładach Sztuczyńskiej (Goscinny, Uderzo, 1966/1993a, s. 14) oraz Kiliana (Goscinny, Uderzo, 1966/1999b, s. 22)

\begin{tabular}{|l|l|l|}
\hline \multicolumn{1}{|c|}{ Oryginal } & \multicolumn{1}{|c|}{ Sztuczyńska } & \multicolumn{1}{c|}{ Kilian } \\
\hline Paraf & Paraf & Autografson \\
Epitaf & Epitaf & Batyskawson \\
Cénotaf & Mordaf & Epitafson \\
Complémenpaf & Grozbaf & Niepotrafson \\
Bellegraf & Tanigraf & Telegrafson \\
Mataf & Mataf & Stenografson \\
Batdaf & Żołdaf & Ogafson \\
& & Paragrafson \\
& & Pornografson \\
\hline
\end{tabular}

Jak widać, tłumaczenie Sztuczyńskiej opiera się w dużej mierze na kalkach językowych, natomiast to Kiliana jest o wiele swobodniejsze. Aby spotęgować komizm, zwiększył on liczbę nazwisk w dymku wedle własnej inwencji, co nie zmienia fabuły, ponieważ owe postaci i tak nie pojawiają się w tym momencie na rysunku. W wersji Kiliana dymek jest o wiele gęściej zapisany, nie sprawia to jednak wrażenia nieczytelności, a jedynie redundancji.

Większość imion i nazwisk w Asteriksie jest stworzona ze zlepków konkretnych francuskich słów, z zaburzeniem zasad ich pisowni lub nawiązaniem do postaci rzeczywistych, a tłumacze muszą wykazać się dużą inwencją przy ich przekładzie. Ciekawym przykładem jest jedno z najdłuższych imion występujących w serii - w oryginale Encorutilfaluquejelesus (Goscinny, Uderzo, 1965b, s. 24) co jest fonetycznym zapisem zdania w czasie zaprzeszłym i trybie łączącym (Encore eût-il fallu que je le susse, czyli 'jeszcze musiałbym o tym wiedzieć'). To typowy przykład zdania w czasie i trybie, które praktycznie nie są używane we współczesnym języku francuskim. U Sztuczyńskiej w imieniu „Jeszczeprzydatniusz” (Goscinny, Uderzo, 1965/1992f, s. 24) pozostało nawiązanie do zaprzeszłości, o tyle istotne w przypadku tej postaci, że jest to rzymski prefekt Lyonu, który od wielu lat marzy o awansie na wyższe stanowisko. Kilian natomiast stworzył imię Salmonellostreptokokus (salmonella + streptokok, czyli paciorkowiec; Goscinny, Uderzo, 1965/1998e, s. 32), które z oryginałem łączy chyba jedynie fakt, że jest niespotykanie długie. Sadowska-Dobrowolska (2015) krytykuje to rozwiązanie: „Ten wybór jest zadziwiający i trudny do zrozumienia, ponieważ nic nie łączy go z wersją oryginalną. Co więcej jest to jedyne imię w całym komiksie, które odnosi się do naukowej nazwy bakterii, co zaburza spójność tłumaczenia” (s. 79). Analiza dokonana przez tę autorkę 
obejmuje jedynie tom Wyprawa dookoła Galii, a w szerszym kontekście kilku tomów, gdy tak wiele imion jest całkowicie zmienianych, wybór dokonany przez Kiliana przestaje razić.

Tym, co znacząco różni tłumaczenia imion przez Kiliana od przekładów Sztuczyńskiej, jest częstsze tworzenie dodatkowych kodowanych treści znaczących, nawiązujących do polskich realiów bądź do charakteru danej postaci. W tomie Tarcza Arwernów - u Kiliana - producent kół z Nemessos (starożytna nazwa Clermont-Ferrand; nota bene jest to czytelna dla Francuzów aluzja do producenta opon Michelin, który ma siedzibę w tej miejscowości) nazywa się Stomilus (Goscinny, Uderzo, 1968/1999d, s. 36), co jest nawiązaniem do nazwy Zakładów Przemysłu Gumowego Stomil. W oryginale bohater ten nosi nieznaczące imię Coquelus (Goscinny, Uderzo, 1968, s. 28), które w tłumaczeniu Sztuczyńskiej brzmi Kuklus (Goscinny, Uderzo, 1968/1993c, s. 28). Sytuacja Kiliana jest jednak o tyle bardziej komfortowa, że - w pierwszym wydaniu w jego przekładzie - dysponuje leksykonem, w którym może wytłumaczyć się z niektórych decyzji i puścić oko do czytelnika: „Skojarzenia, jakie wywołać by mogło imię Stomilusa są, ze względu na zakaz reklamy, niezamierzone" (Goscinny, Uderzo, 1968/1999d, s. 8). To samo dzieje się w przypadku imion rozbójników Pleksusa i Radiusa u Sztuczyńskiej (Goscinny, Uderzo, 1968/1993c, s. 41), które - będąc bezpośrednimi kalkami z francuskiego - nawiązują do łacińskiej nazwy splotu trzewnego. Kilian uznał zapewne, że taka analogia jest niezrozumiała dla większości czytelników, zmienił więc imiona rzezimieszków na Sarkus i Farkus (Goscinny, Uderzo, 1965/1998e, s. 49) co tłumaczy w leksykonie: „Zbójecki duet, którego imiona pochodzą od słynnego bajkowego rozbójnika Sarkifarki" (s. 5). Przykładem postaci, której imię musiało ulec totalnej zmianie, jest centurion Ô Langélus (Goscinny, Uderzo, 1966c, s. 6), przełożony jako Arbuzjusz przez Sztuczyńską (Goscinny, Uderzo, 1966/1992e, s. 6) oraz Dremordus przez Kiliana (Goscinny, Uderzo, 1966/1998d, s. 14). Imię to jest całkowicie nieprzetłumaczalne, znaczy bowiem 'Na Anioł Pański' i wokół niego jest następnie zbudowany gag słowny zagubiony w tłumaczeniach. Oboje tłumaczy postanowiło nadać imię wskazujące na inne cechy bohatera - grubawego (stąd arbuz), wiecznie krzyczącego („drącego mordę”) centuriona. Imiona postaci historycznych pojawiających się w komiksie pozostają bez zmian, niemniej w przekład Asteriksa u Brytów Sztuczyńskiej wkradł się błąd. Zostaje wspomniana postać Cassivellaunusa, historycznego przywódcy ruchu oporu przeciw Cezarowi w Brytanii. Tłumaczka zaś, nie mając świadomości, że mowa o postaci historycznej, przełożyła jego imię na Kabanos (Goscinny, Uderzo, 1966/1992d, s. 6). 


\section{Języki i dialekty}

Spotkania bohaterów serii z osobami posługującymi się innymi niż oni językami bywają często źródłem gagów i kalamburów. Szczególny talent do tworzenia neologizmów i własnych zasad gramatycznych na podstawie zasłyszanych zdań ma Obeliks. Po wysłuchaniu rozmowy centuriona i dekuriona w tomie Złoty sierp bohater u Kiliana zastanawia się: „Większy od centuriona jest chyba millurion?" (Goscinny, Uderzo, 1962/1998f, s. 27), a w wersji Sztuczyńskiej: „Czy nad setnikiem jest tysięcznik?” (Goscinny, Uderzo, 1962/1991b, s. 19). Podczas wizyty w Brytanii bohaterowie mogą przekonać się, że mieszkańcy tej krainy stosują bardzo nietypowy szyk zdania. W tym miejscu wyraźnie ujawnia się nieprzekładalność niektórych żartów z oryginału. Jak pisze Xavier Chantry (2002):

Już w czasie pierwszych lekcji angielskiego uczeń francuski widzi, że w angielskim przymiotnik występuje przed rzeczownikiem, podczas gdy we francuskim znajduje się najczęściej po rzeczowniku. Galowie z komiksu wyciągają $\mathrm{z}$ tego wniosek, że Brytowie umieszczają przymiotnik zawsze odwrotnie niż Galowie, a niekoniecznie przed rzeczownikiem. [...] w polskim systemie językowym miejsce przymiotnika podlega innym regułom niż we francuskim, dosłowny przekaz nie daje więc $\mathrm{w}$ wersji polskiej takiego efektu, jak w wersji francuskiej (s. 50).

Polski czytelnik nie zwróci większej uwagi na to, że Bryt mówi „magiczny napój” zamiast „napój magiczny”, choć na pomysł Obeliksa, aby mówić również „pies mały” zamiast „mały pies”, już owszem (Chantry, 2002, s. 50). W przypadku języka Brytów Sztuczyńska stara się udziwnić składnię tekstu, na wzór oryginału, bardziej niż Kilian. Bryt Pentaks mówi u niej: „Szukać igły w sianie stogu!” (Goscinny, Uderzo, 1966/1992d, s. 29) i „[...] on stan normalny? Czyż ma?” (s. 27) itp., Kilian zaś nie przekształca tekstu aż tak bardzo.

Nie tylko w zetknięciu z obcymi krajami Obeliks ma okazję popisać się lingwistyczną błyskotliwością. Większość akcji tomu Tarcza Arwernów dzieje się w Owernii, krainie leżącej w centralnej Francji, której dialekt charakteryzuje się m.in. substytucją [s] przez [S]. O ile sam efekt nie jest trudny do oddania w tłumaczeniu, o tyle spółgłoska ta występuje w innych miejscach w języku polskim i francuskim, co komplikuje sprawę, gdy na tej cesze wymowy bazuje jakiś kalambur. Po osłuchaniu się już z językiem Owerniaków, Asteriks i Obeliks rozmawiają z pochodzącym $\mathrm{z}$ tego regionu Alembiksem. Rozmowę $\mathrm{w}$ trzech wariantach zaprezentowano w tabeli 2 . 
TABELA 2. Rozmowa Asteriksa i Obeliksa z Alembiksem w tomie Tarcza Arwernów w oryginale (Goscinny, Uderzo, 1968, s. 19) i w przekładach Sztuczyńskiej (Goscinny, Uderzo, 1968/1993c, s. 19) oraz Kiliana (Goscinny, Uderzo, 1968/1999d, s. 27)

\begin{tabular}{|l|l|l|}
\hline \multicolumn{1}{|c|}{ Oryginal } & \multicolumn{1}{c|}{ Sztuczyńska } & \multicolumn{1}{c|}{ Kilian } \\
\hline $\begin{array}{l}\text { Obelix: Nous irons chaser } \\
\text { quelques changliers! }\end{array}$ & $\begin{array}{l}\text { Obeliks: Pójdziemy } \\
\text { upolować kilka dżyków! }\end{array}$ & $\begin{array}{l}\text { Obeliks: Pójdziemy do } \\
\text { laszu zapolować na dziki! }\end{array}$ \\
\hline Alambix: Quelques quoi ? & Alembiks: Kilka czego? & $\begin{array}{l}\text { Alembiks: Dokąd } \\
\text { pójdziecie? }\end{array}$ \\
\hline Asterix: Des sangliers. & Asteriks: Dzików. & Asteriks: Do lasu. \\
\hline $\begin{array}{l}\text { Alambix: Ah, des } \\
\text { changliers! }\end{array}$ & Alembiks: Aha, dżyków! & Alembiks: Aha, do laszu! \\
\hline
\end{tabular}

Rozwiązanie zastosowane przez Sztuczyńską jest o tyle nietypowe, że po raz pierwszy w tym komiksie pojawia się substytucja trójznaku $d z i$ dwuznakiem $d \dot{z}$, ale efekt komiczny zostaje zachowany. Po tym dialogu, trafnie oddanym przez obojga tłumaczy, następuje zwyczajowe „pukanie się w głowę” Obeliksa - gest, który wykonuje zawsze, gdy nie do pojęcia są dla niego obce zwyczaje (często wzmocnione jeszcze słowami: „Ależ głupi ci...”).

\section{Teksty wpisane w obraz}

Oprócz dialogów, świat przedstawiony w Asteriksie tworzą liczne teksty wpisane w kadry. Niektóre są niezbędne dla zrozumienia fabuły, jak np. tabliczki z nazwami miast, do których Galowie przybywają w czasie podróży, inne natomiast służą jedynie do urozmaicenia świata przedstawionego. Te drugie dają tłumaczowi szerokie pole manewru i pozwalają zrekompensować odbiorcy przekładu brak komizmu w innych miejscach.

Numeracja dróg rzymskich na terenie Galii pokrywa się z numeracją współczesnych francuskich dróg krajowych. Gdy więc Asteriks i Obeliks przemieszczają się z Lugundum (obecnie Lyon) do Nicae (dziś Nicea), trafiają na gigantyczny korek zaprzężonych w woły wozów mieszkańców miasta jadących nad morze drogą numer VII (Goscinny, Uderzo, 1965b, s. 28), odpowiadającą współczesnej drodze krajowej N7, która słynie z wielokilometrowych korków w pierwszych dniach wakacji. W tej sytuacji tłumacze nic zmieniać nie musieli, choć aluzja do współczesności niekoniecznie jest zrozumiała dla odbiorcy przekładu. Inaczej jest z napisami przydrożnymi. Przy wjeździe do Durocortorum (Reims), słynącego z szampana, bohaterowie mijają billboard z butelką i napisem - w oryginale: „Demandez un magnum” (s. 17), co oddaje przekład Sztuczyńskiej, po uproszczeniu niezbędnym czytelnikowi polskiemu: „Dwulitrowe 
amfory" (magnum we Francji to półtoralitrowa butelka wina; Goscinny, Uderzo 1965/1992f, s. 17). Kilian natomiast przekształca tekst w: „Piłeś[,] nie jedź” (Goscinny, Uderzo, 1965/1998e, s. 25), co stanowi odniesienie do współczesnej polskiej kampanii społecznej.

Jakub Jankowski (2014, s. 76) pisze, że tłumacze często stają przed dylematem, czy przekładać napisy wpisane w obraz, odejmując wówczas autentyczności światu przedstawionemu, czy też zostawić je w oryginale, ewentualnie dodając przypis. Wydaje się, że w przypadku Asteriksa, gdzie i tak świat przedstawiony ma niewiele wspólnego z rzeczywistością, napisy po polsku nie zaburzają jego realiów, ale i napisy w językach obcych, właściwych odwiedzanym krajom (głównie po łacinie), dodają uroku. Tłumacze stosują też często opcję pośrednią, czyli pozostawienie oryginalnego tekstu w języku obcym i dodanie przypisów na dole strony, poza kadrami komiksu. W tomie Asteriks gladiator bohaterowie korzystają z łaźni publicznej w Rzymie i wchodzą kolejno do apodyterium, sudatorium i caldarium (Goscinny, Uderzo, 1964/1992a, s. 20, 1964/1998a, s. 28). Jedynie Kilian zdecydował się na dodanie gwiazdek do każdego napisu i wytłumaczenie poniżej tych łacińskich nazw pomieszczeń. Tak samo postąpił na kolejnej stronie, gdzie na klatce schodowej pojawiają się tabliczki: „Ostaria [-] pukać dwa razy” i „Proszę wycierać caligae” (s. 29), tłumacząc odbiorcom, że mowa o dozorczyni oraz wycieraniu butów. Sztuczyńska natomiast w tym kadrze zamieniła słowa łacińskie na polskie. Goscinny $\mathrm{w}$ wersji oryginalnej umieścił łacińskie zwroty we wszystkich wymienionych napisach, nie tłumacząc ich znaczenia. Jest to dowód na zwrot do czytelnika dojrzałego, który albo znaczenie tych słów zna, albo jest w stanie (w latach 60 . $\mathrm{XX}$ wieku, gdy wymagało to nieco większego wysiłku niż dzisiaj) znaleźć ich znaczenie w słowniku.

\section{Cytaty i piosenki}

Kwestia przypisów jest też bardzo istotna przy tłumaczeniu łacińskich cytatów. Goscinny zazwyczaj nie zamieszcza francuskiego przekładu, a trzeba przyznać, że często używa cytatów nieoczywistych dla czytelnika niezaznajomionego $\mathrm{z}$ łaciną. Pojawia się więc kolejne wyzwanie kulturowe dla tłumaczy Asteriksa - we Francji łacina była w XX wieku i wciąż jest nierzadko nauczana w szkołach, więc wielu francuskich odbiorców miało z tym językiem styczność podczas edukacji. W krajach nienależących do romańskiego kręgu językowego znajomość łaciny jest rzadkością. Przeciętny odbiorca przekładu nie rozpozna więc słów Wergiliusza: „Timeo Danaos et dona ferentes?” (Goscinny, Uderzo, 1967, s. 17) czy Horacego: „Dulce et decorum est pro patria mori” (Goscinny, 
Uderzo, 1966c, s. 23). Oboje tłumaczy postanowiło znaczenia tych słów wyjaśnić w przypisie (Goscinny, Uderzo, 1967/1993b, s. 17, 1967/1999c, s. 25).

Postacią szczególnie szastającą cytatami - oczywiście zazwyczaj swoimi własnymi - jest Juliusz Cezar. Przytaczane są one często bez przypisów. Gdy dowiaduje się, że tarcza Wercyngetoriksa zaginęła, kwituje to słowami: „Bez komentarzy" (Goscinny, Uderzo, 1968/1993c, s. 18, 1968/1999d, s. 26) w nawiązaniu do dzieła $O$ wojnie galijskiej, które w oryginale i we francuskim przekładzie nosi tytuł Komentarze do wojny galijskiej. Francuski czytelnik musi samodzielnie rozpoznać to autorskie mrugnięcie okiem, natomiast polski ma możliwość dowiedzieć się o nim z przypisu (Goscinny, Uderzo, 1968/1993c, s. 18) lub leksykonu poprzedzającego tekst (Goscinny, Uderzo, 1968/1999d, s. 5). Jeżeli sami autorzy komiksu zdecydowali się na jakiś przypis niebędący elementem świata przedstawionego, zamieszczają go w rogu, w obrębie ramki, na żółtym tle. Oczywiście tłumacz nie może pozostawić takiego miejsca wewnątrz kadru pustego, ale równolegle dodaje też własne przypisy poniżej plansz, co daje wrażenie niespójności i potencjalnie konfunduje czytelnika, który może nie zdawać sobie sprawy z różnej "genezy” tych dodatkowych informacji. Jest to jednak sytuacja nieunikniona, gdy tłumacz uznaje za niezbędne, by wyjaśnić odbiorcy przekładu więcej, niż wyjaśniał czytelnikowi oryginału sam autor.

Specjalnym typem cytatów są fragmenty piosenek, które odgrywają w Asteriksie bardzo ważną rolę. Galowie są narodem rozśpiewanym i dotyczy to nie tylko barda Kakofoniksa, lecz także innych bohaterów nucących urywki piosenek przy codziennych czynnościach czy podczas marszu. O ile w przypadku łacińskich sentencji Sztuczyńska i Kilian przyjęli tę samą metodę pozostawienia tekstu bez zmian, o tyle przy piosenkach obrali dwie różne strategie. Zazwyczaj Goscinny wkładał w usta bohaterów przerobione wersje znanych francuskich piosenek. Tabela 3 pokazuje, $w$ jaki sposób przełożono fragmenty kilku z nich.

Jak widać, podobnie jak w innych miejscach Sztuczyńska zazwyczaj podejmuje decyzję o jak najwierniejszym przekładzie, natomiast Kilian decyduje się na swobodną adaptację. Tłumacz stosuje ten sam zabieg co Goscinny, czyli zmienia słowa współczesnych polskich piosenek, adaptując je do warunków galijskich, co sprawdza się przede wszystkim dlatego, że najczęściej słowa piosenki nie mają większego wpływu na rozwój fabuły. W tym przypadku wierny przekład powoduje zatracenie komizmu sytuacyjno-słownego, a nawet wprowadza konfuzję. Niewiele zrozumie polski czytelnik np. ze słów: „Kocham Galię, piwo, Teutatesa i kobiety o niebieskich oczach!”, które są przełożonymi słowo w słowo zmienionymi przez Goscinnego słowami znanej francuskiej piosenki Charles'a Treneta. 
TABELA 3. Fragmenty piosenek z tomów Złoty sierp, Asteriks i Normanowie, Walka wodzów oraz Asteriks gladiator w oryginale (Goscinny, Uderzo, 1962, s. 5, 46;

1966b, s. 14, 7, 42; 1966c, s. 25; 1964, s. 12) i w przekładach Sztuczyńskiej (Goscinny, Uderzo, 1962/1991b, s. 5, 46; 1966/1993a, s. 14, 7, 42; 1966/1992e, s. 25; 1964/1992a,

s. 12) oraz Kiliana (Goscinny, Uderzo, 1962/1998f, s. 13, 54; 1966/1999b, s. 22, 12, 50; 1966/1998d, s. 33; 1964/1998a, s. 20)

\begin{tabular}{|l|l|l|}
\hline \multicolumn{1}{|c|}{ Oryginał } & \multicolumn{1}{|c|}{ Sztuczyńska } & \multicolumn{1}{c|}{ Kilian } \\
\hline Gaule douce Gaule! & Słodka Galio! & Żeby Galia była Galią! \\
\hline Lutèèèèce est une blonde! & $\begin{array}{l}\text { Lutecja jest jak dziewczyna, } \\
\text { jak czara wina! }\end{array}$ & Lutecjo moja Lutecjo! \\
\hline $\begin{array}{l}\text { Je veux revoir ma } \\
\text { Normandiiiie !!! }\end{array}$ & $\begin{array}{l}\text { Pragnę zobaczyć znów mą } \\
\text { Normandię }\end{array}$ & $\begin{array}{l}\text { Każde dziewczę ci to powie, } \\
\text { nie ma to jak wikingowie! }\end{array}$ \\
\hline Le monkix! & Monkiks! & Mniej niż zero! \\
\hline $\begin{array}{l}\text { J'aime la Gaule, la cervoise, } \\
\text { Toutatis, et les femmes les } \\
\text { femmes qui ont les yeux } \\
\text { bleus ! }\end{array}$ & $\begin{array}{l}\text { Kocham Galię, piwo, Teu- } \\
\text { tatesa i kobiety o niebie- } \\
\text { skich oczach! }\end{array}$ & $\begin{array}{l}\text { Przybyli Galowie pod } \\
\text { okienko, przybyli Galowie } \\
\text { pod okienko. Stukają puka- } \\
\text { ją wpuść panienko! }\end{array}$ \\
\hline $\begin{array}{l}\text { Nous sommes les joyeux } \\
\text { bûcherons! } \\
\text { (Quelle tristesse de voir un } \\
\text { ami abattu !**) }\end{array}$ & $\begin{array}{l}\text { My jesteśmy weseli drwale! } \\
\text { (Jak smutno jest widzieć } \\
\text { powalonego przyjaciela!) }\end{array}$ & $\begin{array}{l}\text { W tym gaju tak ponuro, że } \\
\text { aż przeraża mnie! (A moje } \\
\text { drzewko ścięte i mnie sa- } \\
\text { motnej źle!) }\end{array}$ \\
\hline $\begin{array}{l}\text { Il était une petite galère, il } \\
\text { était une petite galère qui } \\
\text { n'avait ja ja jamais naviguée } \\
\text { ohé ohé ! }\end{array}$ & $\begin{array}{l}\text { Była sobie mała galera, była } \\
\text { sobie mała galera, która ni } \\
\text { ni nigdy nie żeglowała hej } \\
\text { ohej! }\end{array}$ & $\begin{array}{l}\text { Ach jak przyjemnie kołysać } \\
\text { się wśród fal, galera pruje } \\
\text { wodę i płynie sobie w dal! }\end{array}$ \\
\hline
\end{tabular}

* Poniżej kadru przypis, że są to słowa popularnej piosenki.

** Słowa wypowiedziane przez obecną w kadrze sowę.

\section{Treści zagubione - treści dodane}

Komizm sytuacyjny Ateriksa, oparty zazwyczaj na warstwie graficznej, na szczęście pozostaje niezmienny niezależnie od kraju i kultury odbiorcy. Zazwyczaj treściami zagubionymi w tłumaczeniu są elementy komiczne zrozumiałe dla dorosłego czytelnika, opierające się na dwuznaczności jakiegoś elementu humorystycznego, językowego lub językowo-graficznego. Braki te zazwyczaj nie zaburzają odbioru fabuły (może z wyjątkiem kalamburu z komiksu Asteriks legionista, opartego na rymowaniu treści zakodowanych w piktogramach z wypowiedziami bohaterów; Goscinny, Uderzo, 1967, s. 33), powodują jednak jej spłycenie. 
Tytuł jednego z tomów, Tour de Gaulle d'Asterix, jest aluzją do nazwy wyścigu Tour de France, co oczywiście ginie w polskiej wersji (Wyprawa dookoła Galii). W komiksie Tarcza Arwernów Asparanoiks mówi do jednego z pracowników łaźni publicznej: „Moi Galowie są w pełnym” (Goscinny, Uderzo, 1968/1993c, s. 12, 1968/1999d, s. 20), mając na myśli basen, w którym kąpią się Asteriks i Obeliks. Jest to dosłowne tłumaczenie zdania „Mes gaulois sont dans la plaine” (Goscinny, Uderzo, 1968, s. 12) i nie niesie żadnych dodatkowych treści. Oryginał jest natomiast nawiązaniem do słów popularnej przeróbki marszu wojskowego, Marche Lorraine: „Les Gaulois sont dans la pleine [Galowie są na równinie]", co daje komiczny efekt. W Asteriksie u Brytów Mentafiks opisuje swój statek: „Jest wprawdzie mniejszy niż ogródek mego stryja, ale większy niż hełm mego siostrzeńca" (Goscinny, Uderzo, 1966/1992d, s. 11). Polski czytelnik nie zrozumie, że jest to parodia fragmentu popularnego francuskojęzycznego podręcznika do nauki angielskiego z lat 60. XX wieku. Ze względu na kontekst kulturowy tego typu kalambury są całkowicie nieprzetłumaczalne. Kilian w swoim przekładzie stara się jednak zrekompensować czytelnikowi zagubione treści komiczne w innych miejscach. W sposób równie błyskotliwy co Goscinny puszcza oko do dorosłego czytelnika, czasem nawet tam, gdzie oryginał nie zawierał elementów komicznych. Można powiedzieć, że spełnia wówczas postulat Klingberga o zachowaniu tego samego stopnia adaptacji tekstu, ponieważ dostosowuje go, tak jak autorzy oryginału, do podwójnego odbiorcy. W Tarczy Arwernów słychać dobiegający z jednego z domków w wiosce krzyk i jeden z Galów pyta: „To ryczy z bólu ranny dzik?” (Goscinny, Uderzo, 1968/1999d, s. 14). W Wyprawie dookoła Galii Obeliks kłóci się z innym Galem o to, kto pobije jednego Rzymianina, i mówi: „Mój ci on!” (Goscinny, Uderzo, 1965/1998e, s. 15). Kilian tworzy więc nowe nawiązania intertekstualne. W tym samym tomie Galowie przemierzają również ulice Lutecji, gdzie dwóch mieszkańców dyskutuje: „Maluchem wszędzie zaparkujesz!” (s. 21), wskazując na niewielki konny wóz, co zarówno u Sztuczyńskiej, jak i w oryginale nie konotuje nazwy żadnego konkretnego modelu samochodu.

Typowym zabiegiem humorystycznym w Asteriksie jest powielanie przez kilka postaci w jednym kadrze związków frazeologicznych o tej samej tematyce. Maszerujący rzymscy legioniści, zakamuflowani za pomocą liści oraz gałęzi drzew, rozmawiają: „[...] drżę jak liść... / gdzie drwa rąbią, tam wióry lecą / On się uważa za szychę" itd. (Goscinny, Uderzo, 1966/1992e, s. 10; 1966/1998d, s. 18). Ten sam zabieg stosuje autor w Asteriksie i Kleopatrze, gdy bohaterom grozi pożarcie przez krokodyle: „Zgryźliwy gość / Umie się odgryźć / Nie cedzi słów przez zęby" itd. (Goscinny, Uderzo, 1965/1992c, s. 13; 1965/1998d, s. 21). Tłumacze radzą sobie bez problemu z zastąpieniem 
francuskich frazeologizmów polskimi odpowiednikami. Sztuczyńskiej zdarza się jednak pomijać mniej wyeksponowane gry językowe. Podczas jednej z potyczek między Galami a Rzymianami u Kiliana widać dymki z eksklamacjami: „Na Jowisza! / Na Teutatesa! / Na litość boską!” (Goscinny, Uderzo, 1965/1998e, s. 15), co oddaje grę słów z oryginału: „Par Jupiter ! / Par Toutatis ! / Par pitié !” (Goscinny, Uderzo, 1965b, s. 7). Sztuczyńska natomiast przekłada po prostu: „Na Jowisza! / Na Teutatesa! / Litości!” (Goscinny, Uderzo, 1965/1992f, s. 7). To samo dzieje się $\mathrm{w}$ dialogu, w którym dowcip bazuje na redundancji wykrzyknień - u Kiliana: „Na Izydę! Co zrobić? / Na Belenosa! Zbudujemy mury obronne! / Na Belisamę! Masz rację! / Na przykład... czy możemy już sobie pójść?" (Goscinny, Uderzo, 1965/1998b, s. 46). Sztuczyńska zaś ostatnią replikę przekłada następująco: „Czy przypadkiem nie moglibyśmy odejść?” (Goscinny, Uderzo, 1965/1992c, s. 38), niwelując komizm słowny. Są to więc elementy, które mogły w tłumaczeniu nie zaginąć, w pierwszym polskim wydaniu jednak zaginęły. Błyskotliwa aluzja kulturowa występuje na początku tomu Asteriks i Kleopatra. Przybywający z Egiptu Numernabis wita się z Panoramiksem aleksandrynem, co druid tłumaczy innym Galom: „C’est un alexandrin !” (Goscinny, 1965a, s. 7) - 'to aleksandryn / aleksandryjczyk', ponieważ po francusku słowa te są homonimami. Aby oddać ten żart, Kilian wkłada w usta Panoramiksa słowa: „To aleksandryjczyk, mówi aleksandrynem!” (Goscinny, Uderzo, 1965/1998b, s. 15), a powitanie Egipcjanina faktycznie składa się z dwunastu sylab. W wersji Sztuczyńskiej natomiast wypowiedź Numernabisa nie jest aleksandrynem, a Panoramiks mówi po prostu: „To aleksandryjczyk!” (Goscinny, Uderzo, 1965/1992c, s. 7).

\section{Zakończenie}

Przywołane w artykule przykłady to jedynie niewielka część elementów komicznych występujących w omawianych tomach Asteriksa, które skrzą się humorem praktycznie w każdym kadrze. Zróżnicowanie typów komizmu jest dowodem na wieloadresowość utworów Goscinnego i Uderzo. Oczywiste jest, że żadnemu tłumaczowi nie uda się wiernie i ekwiwalentnie przedstawić zagranicznemu odbiorcy wszystkich aluzji, subtelności oraz dwuznaczności oryginału. Głębokie zakorzenienie tego cyklu komiksów w kulturze francuskiej sprawia, że wiele treści komicznych pozostaje nieprzetłumaczalnych. Jest to zapewne jeden z powodów, dla których na polskim rynku komiksy z serii Asteriks są traktowane przede wszystkim jako teksty adresowane do dzieci, podczas gdy we Francji czytają je wszyscy. 
Anthea Bell (1980), niezwykle uznana tłumaczka literatury dziecięcej, m.in. Asteriksa, na angielski, stworzyła „instrukcję” przekładu komiksów Goscinnego i Uderzo, która zawierała np. następujące rady:

a. Celem jest jak najwierniejsze oddanie wrażenia [the feel] wywieranego przez oryginał.

b. W przypadku humoru o tak werbalnej naturze [jak w Asteriksie] tłumaczenie musi podążać bardziej za duchem niż za dosłownym znaczeniem słów, musimy więc często znajdować żarty inne, lecz [...] o podobnym charakterze co francuskie.

$[\ldots]$

e. Spróbujmy stworzyć taką samą mieszankę żartów jak we francuskim [...]. Są [w oryginale] gagi słowne i wizualne, które spodobają się małemu dziecku, są kalambury oraz gry językowe dla starszych dzieci i jest wyjątkowo wyrafinowany humor dla dorosłych.

f. Miejmy tyle samo żartów, ile było we francuskim [pierwowzorze]. Jeśli któregoś z nich nie możemy oddać $\mathrm{w}$ danym miejscu, spróbujemy go wstawić w innym (s. 132).

Czy Polscy tłumacze zastosowali się do rad Bell, czy zdecydowali się pójść inną drogą? Nie ulega wątpliwości, że Sztuczyńska i Kilian, pracujący na tych samych tekstach, przyjęli odmienne strategie translatorskie w oddawaniu komizmu. Przekład Sztuczyńskiej realizuje jeden z postulatów Kilngberga: jak najmniejsze odbieganie od treści oryginału. Tłumaczka wiernie oddaje komizm przeznaczony dla dzieci, młodszych i starszych. Dba o zachowanie klarowności przekazu i wyjaśnianie za pośrednictwem przypisów mniej zrozumiałych elementów kulturowych. Zdarza się jej jednak pomijać bardziej wyrafinowane elementy komizmu słownego, które zastępuje treścią oddającą sens pierwowzo$\mathrm{ru}$, ale niewywołującą uśmiechu. Tym samym niezrealizowany pozostaje drugi postulat Kingberga: ekwiwalentne oddanie stopnia adaptacji zastosowanego przez autora w celu dostosowania tekstu do danego adresata (w tym przypadku podwójnego). Kilian oczywiście również pomija niektóre nieprzekładalne gagi. Niemniej jednak, stara się - zgodnie z postulatem Bell - wynagrodzić to czytelnikowi w innym miejscu. Pozwala sobie na dodawanie nowych treści komicznych, dostosowywanie ich do polskich realiów, co z pewnością nie jest przeciwne zamysłowi autorów. Dba przede wszystkim o oddanie „ducha” komiksu, co skutkuje stworzeniem przekładu będącego równocześnie adaptacją (w rozumiemiu przyjętym przez Oittinen). Choć adaptacja zwyczajowo związana jest $\mathrm{z}$ odbiorcą dziecięcym, $\mathrm{w}$ tym przypadku, paradoksalnie, wykonany zostaje zwrot w stronę czytelnika dorosłego. Czytelnik dziecięcy nie jest jednak 
zaniedbany; historia i tak będzie go najpewniej bawić ze względu na aspekty komiczne przeznaczone dla jego sposobu percepcji. Sytuacja Kiliana jest też o tyle bardziej komfortowa, że dysponuje bardzo praktycznym narzędziem w postaci leksykonu. Umożliwia on, z jednej strony, przybliżenie czytelnikowi świata przedstawionego, $\mathrm{z}$ drugiej zaś - wytłumaczenie się z pewnych translatorskich rozwiązań. W leksykonie niektóre treści adresowane są do czytelników najmłodszych - np. wyjaśnienia, czym są hieroglify (Goscinny, Uderzo, 1965/1998b, s. 6), inne zaś do tych dojrzalszych - jak wskazanie na pojawiającą się w komiksie aluzję do paryskiej sali koncertowej Olimpia (Goscinny, Uderzo, 1966/1999b, s. 7).

Jak wiadomo, przekład starzeje się szybciej niż oryginał. Biorąc więc pod uwagę rosnącą popularność komiksu jako gatunku, niesłabnące zainteresowanie kulturą francuską w Polsce, jak również ponadczasowość dzieł Uderzo i Goscinnego, można przypuszczać, że za jakiś czas ukaże się kolejne polskie tłumaczenie Asteriksa. Byłby to przykład jednej z pierwszych komiksowych serii translatorskich w Polsce.

\section{Bibliografia}

Adamczyk-Grabowska, M. (1988). Polskie tłumaczenia angielskiej literatury dziecięcej. Problemy krytyki przekładu. Wrocław, Warszawa, Kraków: Zakład Narodowy im. Ossolińskich.

Barańczak, S. (2004). Mały, lecz maksymalistyczny Manifest translatologiczny albo: Tłumaczenie się z tego, że tłumaczy się wiersze również w celu wytłumaczenia innym tłumaczom, iż dla większości tłumaczeń wierszy nie ma wytłumaczenia. W: Ocalone w tlumaczeniu (s. 13-62). Kraków: Wydawnictwo a5. (wyd. oryg. 1990). Bell, A. (1980). Translator's notebook. W: N. Chambers (red.), The Signal approach to children's books: A collection (s. 129-139). London: Kestrel.

Busnel, F. (b. d.). Wywiad z Albertem Uderzo - moja prawda. Gildia.pl. Pobrane z: https://www.komiks.gildia.pl/wywiady/moja_prawda.

Cataldi, A. (2009) Nieprzekładalność słownictwa a zawartość podtekstu kulturowego. Rocznik przekładoznawczy, 5, 69-81. https://doi.org/10.12775/RP.2009.005.

Chantry, X. (2002). Stereotypy i ich przekład w komiksie Asterix chez les Bretons i jego polska recepcja. W: E. Skibińska, M. Cieński (red.), Język - stereotyp - przekład (s. 45-55). Wrocław: Dolnośląskie Wydawnictwo Edukacyjne.

Collins Swabey, M. (1961). Comic laughter: A philosophical essay. New Heaven, CT \& London: Yale University Press.

Dąmbska-Prokop, U. (1997). Przekłady na język polski Asterix le Gaulois. W: Śladami tłumacza. Szkice (s. 77-89). Kraków: Viridis. 
Dymel-Trzebiatowska, H. (2017). Skandynawska książka (nie tylko) dla dzieci w czasach transgresji. Jednak Książki, 7, 31-44.

Głowiński, M. (1988). Komizm. W: M. Głowiński, J. Sławiński (red.), Słownik terminów literackich (s. 230). Wrocław: Zakład Narodowy im. Ossolińskich.

Goscinny, R., Uderzo, A. (1962). La Serpe d'or. Paris: Dargaud.

Goscinny, R., Uderzo, A. (1963). Astérix et les Goths. Paris: Dargaud.

Goscinny, R., Uderzo, A. (1964). Astérix gladiateur. Paris: Dargaud.

Goscinny, R., Uderzo, A. (1965a). Astérix et Cléopâtre. Paris: Dargaud.

Goscinny, R., Uderzo, A. (1965b). Le Tour de Gaule d'Astérix. Paris: Dargaud.

Goscinny, R., Uderzo, A. (1966a). Astérix chez les Bretons. Paris: Dargaud.

Goscinny, R., Uderzo, A. (1966b). Astérix et les Normands. Paris: Dargaud.

Goscinny, R., Uderzo, A. (1966c). Le Combat des chefs. Paris: Dargaud.

Goscinny, R., Uderzo, A. (1967). Astérix légionnaire. Paris: Dargaud.

Goscinny, R., Uderzo, A. (1968). Le Bouclier arverne. Paris: Dargaud.

Goscinny, R., Uderzo, A. (1990). Przygody Gala Asteriksa (A. Frybes, tłum.). Warszawa: Egmont Polska. (wyd. oryg. 1961).

Goscinny, R., Uderzo, A. (1991b). Złoty sierp (J. Sztuczyńska, tłum.). Warszawa: Egmont Polska. (wyd. oryg. 1962).

Goscinny, R., Uderzo, A. (1992a). Asteriks gladiator (J. Sztuczyńska, tłum.). Warszawa: Egmont Polska. (wyd. oryg. 1964).

Goscinny, R., Uderzo, A. (1992b). Asteriks i Goci (J. Sztuczyńska, tłum.). Warszawa: Egmont Polska. (wyd. oryg. 1963).

Goscinny, R., Uderzo, A. (1992c). Asteriks i Kleopatra (J. Sztuczyńska, tłum.). Warszawa: Egmont Polska. (wyd. oryg. 1965).

Goscinny, R., Uderzo, A. (1992d). Asteriks u Brytów (J. Sztuczyńska, tłum.). Warszawa: Egmont Polska. (wyd. oryg. 1966).

Goscinny, R., Uderzo, A. (1992e). Walka wodzów (J. Sztuczyńska, tłum.). Warszawa: Egmont Polska. (wyd. oryg. 1966).

Goscinny, R., Uderzo, A. (1992f). Wyprawa Asteriksa dookoła Galii (J. Sztuczyńska, tłum.). Warszawa: Egmont Polska. (wyd. oryg. 1965).

Goscinny, R., Uderzo, A. (1993a). Asteriks i Normanowie (J. Sztuczyńska, tłum.). Warszawa: Egmont Polska. (wyd. oryg. 1966).

Goscinny, R., Uderzo, A. (1993b). Asteriks legionista (J. Sztuczyńska, tłum.). Warszawa: Egmont Polska. (wyd. oryg. 1967).

Goscinny, R., Uderzo, A. (1993c). Tarcza Arwernów (J. Sztuczyńska, tłum.). Warszawa: Egmont Polska. (wyd. oryg. 1968).

Goscinny, R., Uderzo, A. (1998a). Asteriks gladiator (J. Kilian, tłum.). Warszawa: Egmont Polska. (wyd. oryg. 1964). 
Goscinny, R., Uderzo, A. (1998b). Asteriks i Kleopatra (J. Kilian, tłum.). Warszawa: Egmont Polska. (wyd. oryg. 1965).

Goscinny, R., Uderzo, A. (1998c). Asteriks u Brytów (J. Kilian, tłum.). Warszawa: Egmont Polska. (wyd. oryg. 1966).

Goscinny, R., Uderzo, A. (1998d). Walka wodzów (J. Kilian, tłum.). Warszawa: Egmont Polska. (wyd. oryg. 1966).

Goscinny, R., Uderzo, A. (1998e). Wyprawa dookoła Galii (J. Kilian, tłum.). Warszawa: Egmont Polska. (wyd. oryg. 1965).

Goscinny, R., Uderzo, A. (1998f). Złoty sierp (J. Kilian, tłum.). Warszawa: Egmont Polska. (wyd. oryg. 1962).

Goscinny, R., Uderzo, A. (1999a). Asteriks i Goci (J. Kilian, tłum.). Warszawa: Egmont Polska. (wyd. oryg. 1963).

Goscinny, R., Uderzo, A. (1999b). Asteriks i Normanowie (J. Kilian, tłum.). Warszawa: Egmont Polska. (wyd. oryg. 1966).

Goscinny, R., Uderzo, A. (1999c). Asteriks legionista (J. Kilian, tłum.). Warszawa: Egmont Polska. (wyd. oryg. 1967).

Goscinny, R., Uderzo, A. (1999d). Tarcza Arwernów (J. Kilian, tłum.). Warszawa: Egmont Polska. (wyd. oryg. 1968).

Goscinny, R., Uderzo, A. (2013). Galijskie początki (M. Puszczewicz, tłum.). Warszawa: Egmont Polska. (wyd. oryg. 2003).

Jankowski, J. (2014). O przekładzie komiksu, czyli uwagi teoretyczno-praktyczne o tłumaczeniu graficznym. Między Oryginałem a Przekładem, 20, 67-85.

Kessler, P. (1995). The Complete Guide to Asterix. London: Hodder.

Klingberg, G. (1976). The different aspects of research into the translation of children's books and its practical application. W: G. Klingberg, M. Orvig, S. Amor (red.), Children's books in translation: The situation and the problems (s. 84-89). Stockholm: Almqvist \& Wiksell International.

Klingberg, G. (1986). Children's fiction in the hands of the translators. Lund: Gleerup. Krajewska, K., Lipińska, E. (2013). Przekład komiksów - przekład audiowizualny?. W: A. Filipek, M. Osiecka, A. Kamińska (red.), Wkład w przekład 2. Materiały pokonferencyjne 8. Studenckich Warsztatów Tłumaczeniowych Zapętleni w przekładzie (s. 207-215). Kraków: Korporacja Ha!art.

Obremski, W. (2005). Krótka historia sztuki komiksu w Polsce (1945-2003). Toruń: Adam Marszałek.

Oittinen, R. (1993). I am me - I am the Other: On the dialogics of translating for children. Tampere: University of Tampere.

Oittinen, R. (2000). Translating for children. New York, NY \& London: Garland.

Pindel, T. (2005). Tłumacz scenarzystą - Mafalda po polsku. Kilka uwag o przekładzie komiksu. Między Oryginałem a Przekładem, 10, 113-124. 
Sadowska-Dobrowolska, K. (2015). Le Tour de Pologne d'Astérix ?. Traduire, 232, 6785. https://doi.org/10.4000/traduire.698.

Shavit, Z. (1986). Poetics of children's literature. Athens, GA, London: University of Georgia Press.

Teodorowicz-Hellman, E. (1997). Komizm w przekładzie prozy dla dzieci (Pippi Pończoszanka Astrid Lindgren po polsku). W: P. Fast (red.), Komizm a przekład (s. 197-212). Katowice: Śląsk.

Wróblewski, M. (2011). Komiks a literatura. Narracyjne zabawy literackie na przykładzie Tristama Shandy'ego Martina Rowsona. W: G. Gajewska, R. Wójcik (red.), Kontekstowy miks. Przez opowieści graficzne do analiz kultury współczesnej (s. 53-67). Poznań: PTPN. 